\title{
Call for action to protect free exchange of ideas
}

\section{A US law that limits trade to embargoed countries is now affecting scientists' activities.}

Sir - Scientists and engineers need to take action to minimize the collateral damage to science caused by the war on terrorism. At issue here are US prohibitions on providing goods and services to people in countries embargoed by the United States, including Iran, Burma, Sudan and Cuba (see "Publishers split over response to US trade embargo ruling" Nature 427, 663; 2004).

Reversing an earlier ruling, the US Treasury ruled on 2 April that the Institute of Electrical and Electronics Engineers (IEEE) could edit and publish papers submitted by Iranians without obtaining a special licence. However, the same ruling "would consider a prohibited exportation of services to occur when a collaborative interaction takes place between an author in a Sanctioned Country and one or more US scholars resulting in co-authorship or the equivalent thereof".

The implications of these rulings are severe. In 2003, more than 200 scientific articles were jointly written by authors with both Iranian and US addresses. A dozen or more English-language journals are published in Iran, and a few Americans sit on their editorial boards, occasionally publish articles in them, and often are sent manuscripts by their editors for review. At least one US university has advised its faculty not to review manuscripts sent to them by editors of Iranian journals. Scientists are vulnerable, at least theoretically, to large fines for violating these embargo laws. The IEEE continues to deny all member services to people in embargoed countries, including awards and advancement to fellow status.

While there is no indication that the US Treasury is targeting the scientific community, at least one scientific society has already run into trouble: the International Union of Pure and Applied Chemistry was fined for an illegal currency transaction that involved a small expenses payment to a Russian scientist, who unexpectedly cleared the cheque through an embargoed Russian university.

These rulings raise important issues for US scientists and their colleagues around the world. As the Association of American University Presses pointed out in a press release on 5 April, these rulings represent bureaucratic overreaching by the government. They provide no conceivable benefit to international security. Indeed, scientists and engineers in Iran and other embargoed countries are just the sort of people to whom Western democracies should reach out. They are well educated, often familiar with Western institutions, and technologically literate. They often occupy responsible positions in their countries.

The rulings should be a call to action by scientific and professional societies, and indeed to all groups interested in the free exchange of ideas. The academic and scientific communities in the United States need to respond to these challenges, preferably coordinated by the National Academy of Sciences and the National Academy of Engineering.

The international scientific community is also affected, and should protest loudly against these restrictions.

\section{Kenneth R. Foster}

Department of Bioengineering, University of Pennsylvania, 120 Hayden Hall, 3320 Smith Walk, Philadelphia, Pennsylvania 19104-6392, USA

\section{Efforts to help Africa are tripped up by red tape}

Sir - Your Editorial "A fair deal for all" (Nature 428, 451; 2004) recommends that the United Nations Educational, Scientific and Cultural Organization (UNESCO) should expand its agreements to redistribute used instruments to scientists in poorer countries. Having run the Scientific Apparatus Recycling Scheme (SARS) for the Federation of European Biochemical Societies (FEBS) since 1991, and also being involved in the support of African biochemists by UNESCO, I fear that unless the administration of UNESCO grants can be greatly simplified, it will be increasingly difficult to find scientists with the appropriate experience to undertake this voluntary work.

Since 1999 I have received a series of small grants from UNESCO to support the provision of small quantities of biochemicals and spare parts to African scientists. The grants are paid to my university account so that the cost of the goods can be charged to this account by the suppliers, who then dispatch direct to Africa. This arrangement simplifies the task for the recipients and avoids multiple currency conversions, but involves many e-mails to ensure that the correct goods are delivered. The main problem I have had is with the bureaucracy of UNESCO, which - although designed to ensure that I operate honestly - has little understanding of the problems at the coal face.

In the case of my most recent grant, I was told in December 2002 that I would receive US $\$ 10,000$ but, after much correspondence concerning the contract, which was issued in May, I received \$8,500 the following November and $\$ 1,308$ in January 2004, with no explanation of the shortfall. I had budgeted carefully against an exchange rate of $\$ 1.6$ to $£ 1$, but by January the dollar had fallen to 1.85 . As a consequence of this and of the shortfall in funds, I was left $\mathfrak{£} 300$ in debt. I informed UNESCO of this but have had no redress.

My wish is that UNESCO would operate like granting bodies in the United Kingdom: telling the recipient the grant available, promptly transferring the full funds and demanding a precise statement of the expenditure. If recipients do not perform correctly they know they will receive no further grants.

My experience with the SARS programme has been mostly positive. Since 1992, 107 loads of books, journals and apparatus have been sent to the FEBS societies in central and eastern Europe at a

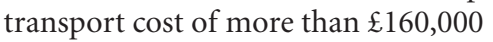

(US\$286,000). Most of the gifts have come from the United Kingdom but SARS also covers the cost of transport between countries on the European mainland. I think that if one started to charge for used instruments, as in some of the schemes mentioned in the Editorial, the administrative expenses would climb considerably.

Finally, your Editorial and later correspondence by Stevens Rehen et al. ("Scientific aid to Brazil is strangled by red tape" Nature 428, 601; 2004) noted customs barriers to scientific donations. I have had considerable difficulty with certain countries but often, if a nominal value is stated for each piece of equipment, the customs are satisfied. It also helps to get the load classified as humanitarian aid rather than technical aid, in order to avoid taxes, but this may take several months. A more positive attitude by governments to our problems would be welcome, but politicians often tell us "The customs are a law unto themselves".

Peter N. Campbell

Department of Biochemistry and Molecular Biology, University College London, London WC1E 6BT, UK

\section{correspondence}

Contributions to Correspondence may be submitted to corres@nature.com. They should be no longer than 500 words, and ideally shorter. 